\title{
Occipital spur: understanding a normal yet symptomatic variant from orthodontic diagnostic lateral cephalogram
}

\author{
Eby Varghese, ${ }^{1}$ Renu Sarah Samson, ${ }^{2}$ Sumanth Nagraj Kumbargere, ${ }^{3}$ Minoo Pothen ${ }^{4}$
}

${ }^{1}$ Paediatric Dentistry, Faculty of Dentistry, Melaka-Manipa Medical College, Bukit Baru, Malaysia

${ }^{2}$ Orthodontics, Faculty of Dentistry, Melaka-Manipal Medical College, Bukit Baru, Malaysia

${ }^{3}$ Oral Medicine, Faculty of Dentistry, Melaka-Manipal Medical College, Melaka, Malaysia

${ }^{4}$ Department of Psychiatry, Faculty of Medicine, MelakaManipal Medical College, Bukit Baru, Malaysia

\section{Correspondence to} Dr Renu Sarah Samson Dr, renusamson@gmail.com, renusarah.samson@manipal. edu.my

Accepted 8 May 2017

\section{CrossMark}

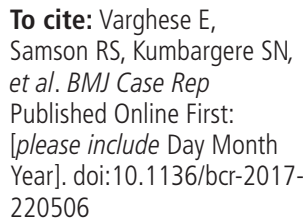

\section{DESCRIPTION}

Occipital spurs, also called as occipital knob, occipital bun, chignon or inion hook, is an exaggerated external occipital protuberance (EOP). It is frequently discussed in anthropological literature as a Neanderthal trait but hardly reported and considered as a normal variant in medical literature. It is a frequent finding among males and hence a prominent occipital spur is often used in gender determination in forensic investigations. ${ }^{1}$ EOP can be of three different types: type I, smooth; type II, crest form; type III, spine form.

Even though a normal variant, such hyperostoses can become symptomatic and cause much concern to patients. Most patients complain of a tender bony swelling at the back of the neck causing pain especially while lying down. Pain may be present at rest and during neck movements. It often presents in late adolescence due to the growth spurts, and as the protuberance grows in size it causes subperiosteal stretching resulting in tenderness. ${ }^{2}$ Some patients, especially those with short hair, may complain that it looks unaesthetic. Resection of the hyperostosis surgically and smoothening of the bone can bring about adequate recontouring to relieve the symptoms. Such surgical procedures are considered relatively safe as there is no risk of intracranial penetration, the scarring is minimal and hidden by the hair and hence considered to be the best way of management of such cases.

A young female adult patient visited the department of orthodontics with a complaint of

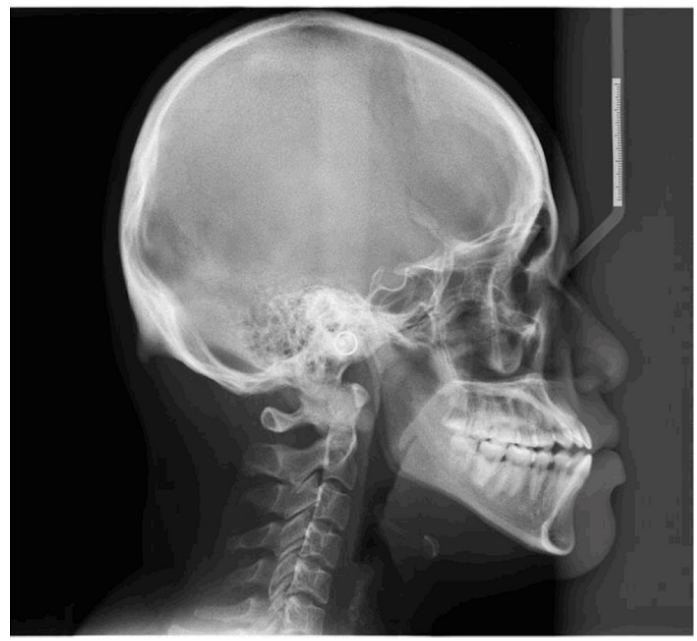

Figure 1 Occipital spur as seen on lateral cephalogram of the patient.

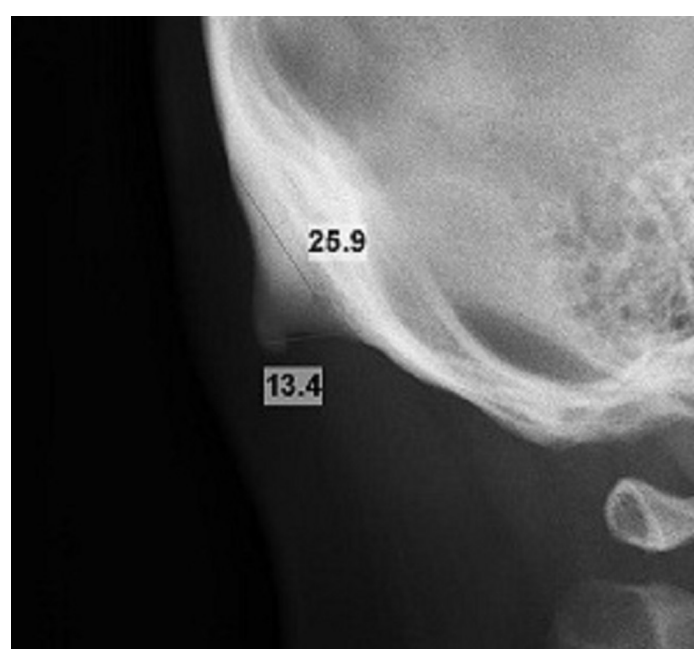

Figure 2 Dimensions of the occipital spur as measured from radiograph (width at base $25.9 \mathrm{~mm}$ and standing at a height of $13.4 \mathrm{~mm}$ above the normal outline of occipital bone.

malaligned teeth. On examination, she had an edge-to-edge bite and a bilateral class III molar and canine relationship. Mild anterior open bite and an associated tongue thrusting habit was also seen. A high mandibular plane angle was noticeable clinically and was later confirmed on the lateral cephalogram. She was otherwise healthy and general examination revealed no gross signs/symptoms of disease/pathology.

Lateral cephalogram taken for orthodontic diagnostic purposes was studied carefully. A skeletal class III pattern with high mandibular plane angle was confirmed and a focal spine-like hyperostosis was seen in the occipital protuberance extending in a craniocaudal direction (figure 1). The measurements on the radiograph showed that the spur had a width of $25.9 \mathrm{~mm}$ at its base and stood $13.4 \mathrm{~mm}$ above the normal outline of the occipital bone (figure 2). This coincidental radiographic finding was confirmed to be occipital spur (type III EOP). Type III EOP is an unusual finding among females and reported in only $4.2 \%$ of them. When asked about associated symptoms, the patient said that she experienced tenderness over the area especially while lying down on hard surfaces. On examination, a palpable bony swelling was noticed with no discharge or infection. During palpation, she said that the protuberance was slightly tender. The condition was explained to the patient and she was advised the use of soft pillows to relieve the 


\section{Learning points}

- Orthodontic diagnostic radiographs must be studied carefully to assess other possible abnormalities of the head and neck region apart from the teeth and jaws. Most often such 'chance discoveries' that are usually overlooked can help diagnose serious health conditions early and which on proper treatment can tremendously improve the quality of life.

- Orthodontists can be extremely helpful in diagnosing and referring patients whose radiographs reveal such anomalies/ variations and therefore, it is of utmost importance that they spend time studying radiographs in detail.

- Occipital spurs, if symptomatic, can be managed conservatively with the use of soft pillows and analgesics before embarking on surgical procedures. If symptoms persist, surgical recontouring of the protuberance can be carried out with minimal risk of intracranial penetration. pain. She is currently undergoing orthodontic treatment for the class III malocclusion. She has been referred to an orthopaedic surgeon should the symptoms get aggravated in future.

Contributors EV: manuscript writing; RSS: manuscript editing; SNK: radiography and image editing; MP: literature review and proof-reading.

Competing interests None declared.

Patient consent Obtained.

Provenance and peer review Not commissioned; externally peer reviewed.

(C) BMJ Publishing Group Ltd (unless otherwise stated in the text of the article) 2017. All rights reserved. No commercial use is permitted unless otherwise expressly granted.

\section{REFERENCES}

1 Shahar D, Sayers MG. A morphological adaptation? The prevalence of enlarged external occipital protuberance in young adults. J Anat 2016;229:286-91.

2 Singh R. Bony tubercle at external occipital protuberance and prominent ridges. J Craniofac Surg 2012:23:1873-4.

3 Marshall RC, Abela C, Eccles S. Painful exostosis of the external occipital protuberance. J Plast Reconstr Aesthet Surg 2015;68:e174-e176.

Copyright 2017 BMJ Publishing Group. All rights reserved. For permission to reuse any of this content visit http://group.bmj.com/group/rights-licensing/permissions.

BMJ Case Report Fellows may re-use this article for personal use and teaching without any further permission.

Become a Fellow of BMJ Case Reports today and you can:

- Submit as many cases as you like

- Enjoy fast sympathetic peer review and rapid publication of accepted articles

- Access all the published articles

- Re-use any of the published material for personal use and teaching without further permission

For information on Institutional Fellowships contact consortiasales@bmjgroup.com

Visit casereports.bmj.com for more articles like this and to become a Fellow 